\title{
Onychomycosis: current understanding and strategies for enhancing drug delivery into human nail tissue
}

Rabia Aslam ${ }^{\mathrm{a}}$, Talib Hussain ${ }^{\mathrm{b}}$, Abid Mehmood Yousaf ${ }^{\mathrm{b}}$, Muhammad Usman Ghori ${ }^{\mathrm{c}}$, Ikram Ullah Khan ${ }^{\text {d }}$, Syed A. A. Rizvi and Yasser Shahzad, ${ }^{\text {b,* }}$

${ }^{a}$ Faculty of Pharmacy, University of Central Punjab, Lahore, Pakistan; ${ }^{b}$ Department of Pharmacy, COMSATS University Islamabad, Lahore Campus, Lahore, Pakistan; ${ }^{\circ}$ Department of Pharmacy, School of Applied Sciences, University of Huddersfield, Huddersfield, UK; 'Department of Pharmaceutics, Faculty of Pharmaceutical Sciences, Government College University Faisalabad, Faisalabad, Pakistan; ${ }^{e}$ Department of Pharmaceutical Sciences, Hampton University School of Pharmacy, Hampton University, VA, USA.

\section{*Correspondence}

Dr. Yasser Shahzad

Associate Editorial Board Member

Current Drug Research Reviews

Department of Pharmacy

COMSATS University Islamabad

Lahore Campus

Lahore, Pakistan

Email: y.shahzad@live.com; yshahzad@ cuilahore.edu.pk 


\begin{abstract}
Background: Onychomycosis is by far the most common finger or toe nail fungal infectious disease caused by dermatophytes, non-dermatophytic molds or yeast. It accounts for $50 \%$ of the total nail disorders, and affects patients physically, socially, and psychologically and can seriously influence their quality of life. Objectives: Oral antifungals are routinely used to treat the nail fungal disease; however oral therapy is associated with severe side effects and longer treatment times. In recent years, drug delivery directly into the nail or nail bed has gained attention and various topical products have been tested that can cure the disease when applied topically or transungually. Nevertheless, drug penetration into and through the nail is not straightforward and requires chemicals to improve its permeability or by applying physical stress to promote drug penetration into and through the nail. Topics covered: This lucid review presents an overview of various causes of onychomycosis, current therapeutic approaches, and efforts aimed at increasing the permeability of nails through various strategies such as chemical, physical and mechanical methods for permeation enhancement. Conclusion: Various strategies have been proposed for the treatment of onychomycosis, however, much research into a more precise and effective therapy is still required.
\end{abstract}

\title{
Keywords:
}

Antifungals; dermatophytes; hydration; nail; onychomycosis; permeability; transungual; ungual drug delivery 


\section{Introduction}

Onychomycosis is a common fingernail or toenail bed and associated nail plate fungal infection caused by the dermatophytes, non-dermatophytic moulds or yeast [1]. It is more frequent in toenails, where it often involves several nails [2]. Approximately $90 \%$ of onychomycosis cases, anthropophilic dermatophytes including Trichophyton rubrum and Trichophyton mentagrophytes are the main causative microorganisms. Non-dermatophyte moulds and yeasts are much less common [3]. Common conditions include nail thickening, discoloration, brittleness and often onycholysis [4]. Since nails are necessary for aesthetic appearance, any deterioration and discoloration of nails not only affect patients physically, socially, and psychologically but also hamper their quality of life [5]. Onychomycosis accounts for $50 \%$ of the total fingernail and toenail disorders [6]. In a survey of over 96000 patients in 20 European countries, onychomycosis was diagnosed in $29.6 \%$ of the population [7] and this rate is increasing each year with population ageing [8].

One treatment option for nail fungal disorders is the use of oral antifungals; however, high relapse rates and severe side effects often deemed oral therapy unfavorable. Topical applications of antifungals are more promising as the drug is directly applied to the infected area. Nevertheless, the nail barrier is difficult to disrupt and antifungal drugs are usually poorly water-soluble compounds, thus a limited amount can cross the nail barrier because of its hydrophilicity. Additionally, marketed topical antifungal products have rather slow clearance rates [9].

To this end, this review presents the current understanding of onychomycosis and various treatment options already in practice. It further extends to various strategies of overcoming the nail barrier for the safe and effective delivery of various drugs. These strategies include from an interplay of physicochemical properties and formulation attributes to various physical methods of disrupting the nail barrier functions for effective therapeutic delivery of antifungals.

\section{Anatomy of the nail}

Nail anatomy has been described in detail elsewhere [10-13], therefore, a brief discussion is presented here. Nail, in general, consists of proximal and lateral folds, cuticle, matrix, nail plate, nail bed, and hyponychium (Figure 1). The cuticle, which is a modified form of stratum corneum, protects the nail matrix from infections [14]. Although the human nail plate is somewhat similar to the skin's stratum corneum, it is composed primarily of a highly disulfidelinked laminated keratinized structure that is much denser and thicker than the stratum corneum, and it is comparable to a hydrophilic gel membrane $[15,16]$. The human nail plate is 
generally considered trilaminar i.e. the dorsal, intermediate (softer and thicker layer) and ventral layers; however, physical characteristics demonstrate it as a bilaminar structure. The ventral layer is possibly derived from superficially adherent material that connects the nail and nail bed. Nail resistance to topical antimicrobial agents is therefore a result of an increased thickness and density of ventral layer as the nail grows distally [10-12]. The nail is more prone to water loss because of low lipid contents $(0.1-1 \%)$ compared to the skin which is highly lipidic [13]. The nail has approximately $10 \%$ water content compared to the skin (25\%), and the water loss from the nail is faster than the skin [17]. Because of lower lipid contents, it is believed that nail permeability for hydrophilic compounds would be higher, nevertheless a lipid permeation pathway has also been described for hydrophobic compounds $[9,18]$. The nail plate is a rectangular and translucent structure which is curved in both the longitudinal and transverse axes. The upper surface of nail plate is smooth; however, longitudinal epidermal ridges are present which extend to the lunula [10]. These longitudinal ridges become prominent with aging [10]. The nail bed is present beneath the nail plate and it extends from the distal margin of the lunula to the hyponychium. The nail bed is made of thin epidermal layer which has a low cell division rate and a complement of keratin expression is another point of difference from the epidermis of normal skin where terminal differentiation of keratins is present [19]. Generally, the growth rate of nails is slow; however, fingernails grow slightly faster $(2-3$ $\mathrm{mm} / \mathrm{month})$ than the toenails ( $1 \mathrm{~mm} / \mathrm{month})[14,20]$. In most cases, disease states such as onychomycosis and aging further reduce the nail growth rate [14].

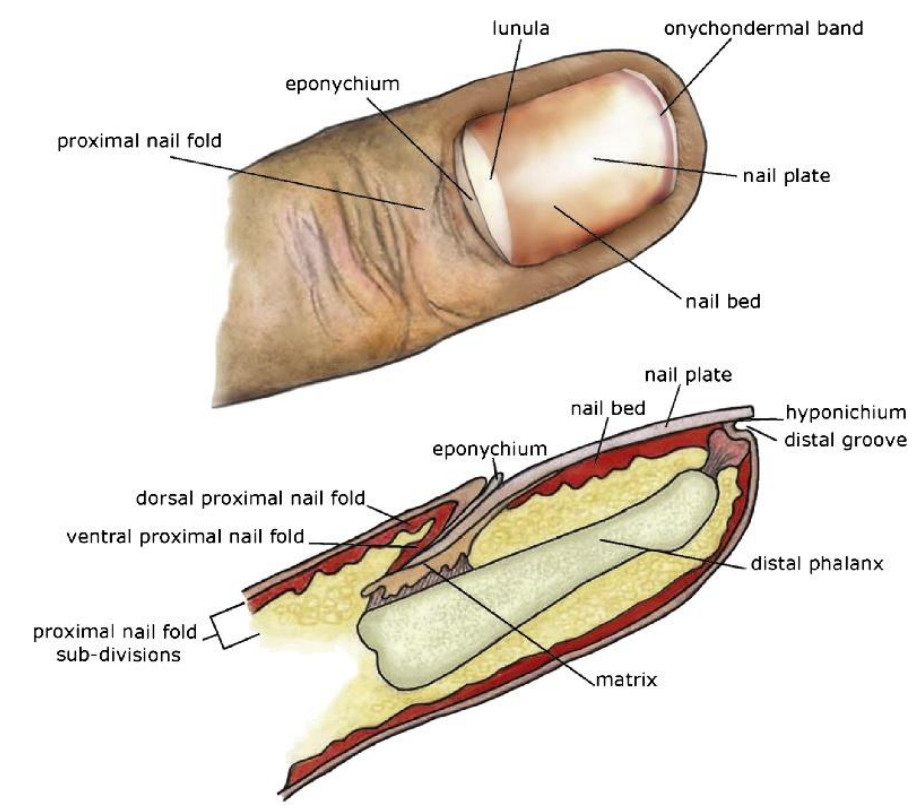

Figure 1: Anatomy of nail. Reproduced with permission from [21]. 


\section{Classification of onychomycosis}

Five major types of onychomycosis or tinea unguium have been identified depending upon the site of nail plate invasion by the fungi [4]. More recently, secondary onychomycosis has also been diagnosed and has been proposed to be the sixth major type of fungal invasion to the nail plate [22]. Onychomycosis classification, clinical manifestations and associated organisms are presented in Table 1. It is now widely accepted that a variety of organisms can attack and break down nail keratin. For example, Scopulariopsis brevicaulis is known for damaging nail for many years and causes distal and lateral subungual onychomycosis. Some other pathogens, such as Fusarium species, can produce distinct changes ranging from paronychia to proximal subungual and in extreme cases total dystrophic onychomycosis may occur [22]. To a lesser extent, Candida species are recognized as the causative agent of primary nail dystrophy after nail plate invasion [23].

Table 1: Types, clinical manifestations of onychomycosis and associated organisms [3, 22]

\begin{tabular}{|c|c|c|}
\hline Type & Clinical manifestation & Associated organisms \\
\hline $\begin{array}{l}\text { Distal and } \\
\text { lateral } \\
\text { onychomycosis }\end{array}$ & $\begin{array}{ll}\text { - } & \text { Hyperkeratosis } \\
\text { - } & \text { Dyschromia including } \\
\text { melanonychia, onycholysis } \\
\text { - Longitudinal streaking in } \\
\text { mid and lateral nail plate } \\
\text { region }\end{array}$ & $\begin{array}{ll}\text { - } & \text { Dermatophytes (Trichophyton } \\
\text { rubrum, Trichophyton } \\
\text { mentagrophytes) } \\
\text { - } \quad \text { Candia albicans } \\
\text { - } \quad \text { Fusarium species } \\
\text { - Scytalidium species } \\
\text { - Scopolariopsis brevicaulis } \\
\end{array}$ \\
\hline $\begin{array}{l}\text { Proximal } \\
\text { subungual } \\
\text { onychomycosis }\end{array}$ & $\begin{array}{ll}\text { - } & \text { Patchy } \\
\text { - } & \text { Striate (transverse or } \\
& \text { longitudinal) } \\
\end{array}$ & $\begin{array}{l}\text { - } \quad \text { Trichophyton rubrum } \\
\text { - } \quad \text { Fusarium species }\end{array}$ \\
\hline $\begin{array}{l}\text { Superficial } \\
\text { white } \\
\text { onychomycosis }\end{array}$ & & $\begin{array}{l}\text { - Dermatophytes (Trichophyton } \\
\text { rubrum, Trichophyton } \\
\text { mentagrophytes) } \\
\text { - } \quad \text { Fusarium species } \\
\text { - Scytalidium species } \\
\end{array}$ \\
\hline $\begin{array}{l}\text { Endonyx } \\
\text { onychomycosis }\end{array}$ & & $\begin{array}{l}\text { - Tinea soudanense } \\
\text { - Tinea violaceum }\end{array}$ \\
\hline $\begin{array}{l}\text { Total dystrophic } \\
\text { onychomycosis }\end{array}$ & & $\begin{array}{l}\text { - Dermatophytes (Trichophyton } \\
\text { rubrum, Trichophyton } \\
\text { mentagrophytes) } \\
\text { - } \quad \text { Candia albicans } \\
\text { - Scytalidium species } \\
\end{array}$ \\
\hline $\begin{array}{l}\text { Secondary } \\
\text { onychomycosis }\end{array}$ & $\begin{array}{ll}\text { - } & \text { Swelling and erythema of } \\
& \text { nail folds } \\
\text { - } & \text { hyperkeratosis } \\
\text { - } & \text { onycholysis } \\
\end{array}$ & $\begin{array}{ll}\text { - } & \text { Candida albicans } \\
\text { - } & \text { Candida parapsilosis } \\
\text { - } & \text { Candida tropicalis } \\
\text { - } & \text { Candida krusei } \\
\end{array}$ \\
\hline
\end{tabular}




\section{Treatment of onychomycosis and associated issues}

Currently, various treatment modalities are available for the management of onychomycosis. These include removal of the infected nail chemically or surgically, and systemic and topical administration of antifungals to eliminate the infectious agent. There are several factors including type of pathogen, clinical manifestation, severity of the infection and co-morbidities that can influence the choice of best possible treatment strategy for onychomycosis [24]. For example, superficial onychomycosis can be best treated with topical antifungals rather than the oral therapy. Similarly, topical treatment could be a good option if one or two nails are infected; however, a systemic treatment should be of choice if several nails are infected concomitantly. In many cases, the patients with onychomycosis also have comorbidities. In such cases, drug interactions are difficult to avoid following an oral therapy [25]. It is noteworthy that systemic treatment with oral antifungal has not been successful to its full potential because of the limited blood circulation into the affected nail bed, which leads to a limited drug quantity being available at the infected site. However, a large number of patients with onychomycosis fail to respond to even a high dose of oral antifungals and developed severe side effects [26]. Moreover various drug resistant strains of microorganisms have emerged due to a long term systemic exposure to the antifungal agents [27].

Since it is difficult and takes significant amount of time to achieve therapeutic levels in the nail after oral delivery of antifungal agents, local delivery of drugs in the form of topical formulations has been proposed. However, limited ingress of chemicals into the nail plate limits the effectiveness of topical formulations. The inadequacies of the current treatments warrants a requirement to develop new and effective site-specific topical treatment modalities for ungual disorders that will reduce the systemic exposure of therapeutic agents [28].

\section{Drug delivery into human nail tissue}

Owing to the treatment failures with oral antifungals, it would appear that topical delivery of antifungal drugs would be the most suitable approach. However, topical delivery of drugs into human nail tissue is not straightforward and requires understanding of various factors influencing the drug penetration across the nail plate. Thus, drug delivery into nail for the treatment of onychomycosis is not only influenced by the morphological and physiological characteristics and composition of nails [29-31], but also by the permeant properties such as molecular size, surface charge, lipophilicity and polarity and the formulation attributes [32, 33]. Here we have presented a succinct overview of the factors influencing drug delivery into nail tissue. 


\subsection{Nail plate characteristics}

Unique nail plate characteristics have substantial impact on drug permeation. These include extent of nail plate hydration, nail plate's keratin content, disease condition and thickness of the nail plate. Among these attributes, disease state is likely to impart massive effect on permeability of the nail plate. Kobayashi and co-workers studied permeation of 5-fluorouracil (5-FU) through nail plates infested with minor fungal infection and compared it with nail plates obtained from healthy volunteers [34]. Nail plates with severe fungal infection were discarded because of their uneven thickness and such plates were collapsed when immersed in water. It is noteworthy that fungal infection resulted in thickening of nail plates thus leading to an increased permeation path-length for the drugs to reach the nail bed. However, results suggested a little difference in the permeation of 5-FU across healthy and fungus infected nail plates, and it would appear that the permeability was dependent on the diffusivity of 5-FU as well as thickness of healthy or infected nail plate. These results also suggested that healthy nail plates can be used as surrogates for infected nails. Nevertheless, the occurrence of dermatophytoma in nails having onychomycosis may cause alteration in the drug diffusivity across the nail plates and may possibly reduce the success rates of systemic and topical therapy $[32,35]$.

Nail hydration is believed to effect transungual drug delivery [36]. As discussed earlier, nail plate behaves like a hydrophilic gel membrane with great affinity to polar or semi-polar solvents [37]. In the presence of water or water miscible solvents such as ethanol, propylene glycol and polyethylene glycols, nail keratin swells and becomes flexible with increased porosity, thus allowing for diffusion of compounds through the nail plate. However, non-polar solvents increase the rigidity of nail keratin, thus reduced or no permeation of compounds is possible [38]. Gunt and Kasting demonstrated a 3-fold increased ketoconazole permeation through human cadaver nails when relative humidity was increased from $15 \%$ to $100 \%$ over a period of 40 days [39]. Similarly, Hui and co-workers compared marketed product, namely Penlac ${ }^{\circledR}$ (organic solvent-based lacquer) with aqueous gel formulations. The results showed an enhanced ciclopirox permeation from aqueous gel formulation compared to marketed product, thus endorsing the role of nail hydration on the transungual drug permeation [40]. More recent study demonstrated an improved permeation of ciclopirox olamine across bovine hooves and healthy human nail clippings using cyclodextrin-poloxamer based hydroalcoholic dispersion. The enhanced permeation was because of an increased nail hydration owing to polar nature of the formulation [41]. 
Nail keratin-drug binding may also affect the topical treatment of nail fungal diseases. Drug binding with keratin lessen the permeant availability and declines the concentration gradient, thus resulting in limited drug penetration [42]. Nevertheless, estimating nail keratin-drug binding is difficult and no conclusive evidences exist of such binding. Therefore, delipidized stratum corneum keratin is often used as a nail keratin surrogate which highlighted interplay of lipophilicity and the drug permeation [43].

\subsection{Permeant characteristics}

Various physical and chemical properties of drugs influence their permeation into and through the nail plate, and have been extensively discussed in previous reports [36, 43, 44]. Therefore, an overview has been presented here. Permeation of drugs through bovine hoof membrane and human nail is often linked with the molecular weight of permeants, i.e. the higher the molecular weight, the lower is the drug penetration [45]. Larger molecules face difficulty in crossing the closely compacted keratin network of nail plate. Kobayashi and coworkers found an inverse relationship between permeability coefficient and molecular weight of the numerous non-ionic and ionic model drugs through human nail [34].

Surface charge is found to play a vital role in penetration of ionizable drug molecules through nail plate. An interesting feature of nail keratin is its isoelectric point, which is in the range of $4-5$ [43]. Thus, the nail keratin acquires a net negative charge at $\mathrm{pH}$ above its isoelectric point whilst a positive charge is carried by the keratins at a $\mathrm{pH}$ below the isoelectric point, thus electrostatic interactions would either increases or decreases the permeability of ionic species [46]. Positively charged molecule will face repulsion at low $\mathrm{pH}$ while a negatively charged molecule will be repelled by nail surface at high $\mathrm{pH}$ situations. The electrostatic association between nail surface and charged ions undergoing diffusion is termed as "Donnan effect" $[47,48]$. In the same way, pyridinium ion being a positively charged ion at $\mathrm{pH} 2.0$ value, is repelled by keratin that also carries a positive charge at this $\mathrm{pH}$ value, consequently reduces the permeability coefficient of pyridinium ion [15].

Partition coefficient has a great impact on diffusion of drug molecules via nail plate. With increase in the carbon chain length or lipophilicity of permeant, permeation of drugs decreases. Decline in permeability coefficient with rise in lipophilicity of permeant is ascribed to hydrophilic character of the nail plate [18, 48]; however, the lipophilicity effect on the permeation of compounds is often less prominent as compared with the molecular weight of the permeant [43]. 


\subsection{Drug formulation characteristics}

Formulations play an important role in overall success of pharmacotherapy. Thus, formulation characteristics are important to ensure precise, safe and effective delivery of drugs for desired pharmacological actions. Formulation types and characteristics have been reviewed extensively elsewhere [36, 49], therefore, a brief discussion is included herein. Diffusion of aqueous soluble permeants via nail plate is facilitated by water. After dilution with water, neat alcohols showed enhanced permeation through nail plate due to swelling of the hydrophilic nail plate. This phenomenon leads to the expansion of keratin mesh causing development of larger pores, thereby facilitating the permeation of the molecules [18]. It was also observed that diffusing molecules need to be in unionized and solubilized form for permeation through nail plate. Attributes of permeants including its water solubility, degree of ionization and interaction with nail plate are determined by $\mathrm{pH}$ of aqueous vehicle. Whereas, $\mathrm{pH}$ of vehicle and $\mathrm{pKa}$ value of permeant influences the degree of ionization of the drug. Generally, basic drugs show unionized behavior at high $\mathrm{pH}$, while acidic drugs stay in their unionized form at low $\mathrm{pH}$. Therefore, it is expected that acidic drugs will permeate efficiently at lower $\mathrm{pH}$, whilst basic drug will permeate efficiently at higher $\mathrm{pH}$ values. Thus, adjusting formulation's $\mathrm{pH}$ could directly impacts the overall performance and success of the therapy [49].

\section{Enhancement of nail permeation of drugs}

Drug delivery through nail is challenging because of its natural barrier properties. The difficulty of permeation of drugs becomes more challenging after fungal infections. Over the past few decades, various strategies from using chemicals to disrupt the nail barrier to physical methods such as iontophoresis, etching, microporation, laser ablations and low frequency ultrasound ablation through to mechanical methods such as avulsions and abrasions have been used. This section briefly summarizes various strategies of enhancing the nail permeation for various drugs, as given in Table 2.

Table 2. Methods of drug penetration enhancement into nail with examples of permeants.

\begin{tabular}{|l|l|l|l|l|l|}
\hline Technique & Permeant & Enhancer & Experimental setup & Brief outcomes & Ref. \\
\hline $\begin{array}{l}\text { Chemical } \\
\text { method }\end{array}$ & Oxiconazole & $\begin{array}{l}\text { N-acetyl } \\
\text { cysteine }\end{array}$ & $\begin{array}{l}\text { Nails clipping were } \\
\text { obtained after } \\
\text { Application of } \\
\text { oxiconazole lotion } \\
\text { on nails healthy } \\
\text { volunteers twice a } \\
\text { day for six weeks. }\end{array}$ & $\begin{array}{l}\text { Improved drug } \\
\text { penetration and retention } \\
\text { in upper layers of nail. }\end{array}$ & {$[50]$} \\
& & & & \\
& & & & \\
\hline
\end{tabular}




\begin{tabular}{|c|c|c|c|c|c|}
\hline & Econazole & $\begin{array}{l}\text { 2-n-nonyl- } \\
\text { 1,3-dioxolane }\end{array}$ & $\begin{array}{l}\text { Finger nail plates } \\
\text { obtained Healthy } \\
\text { human. }\end{array}$ & $\begin{array}{l}\text { Econazole penetrates the } \\
\text { nail six-times more as } \\
\text { compared to an identical } \\
\text { lacquer without } \\
\text { enhancers. }\end{array}$ & [51] \\
\hline & Keratinase & $\begin{array}{l}\text { Keratolytic } \\
\text { enzymes }\end{array}$ & $\begin{array}{l}\text { Bovine hoof } \\
\text { membranes as model } \\
\text { nail plate }\end{array}$ & $\begin{array}{l}\text { Enhanced drug } \\
\text { permeation across bovine } \\
\text { hoof membranes. }\end{array}$ & [52] \\
\hline & Terbinafine HCL & $\begin{array}{l}\text { Sodium } \\
\text { phosphate }\end{array}$ & $\begin{array}{l}\text { Human cadaver nail } \\
\text { in a Franz diffusion } \\
\text { cell. }\end{array}$ & $\begin{array}{l}\text { Enhanced drug } \\
\text { permeation across human } \\
\text { nail plate. }\end{array}$ & [53] \\
\hline & Voriconazole & $\begin{array}{l}\text { Thioglycolic } \\
\text { acid }(5 \%)\end{array}$ & $\begin{array}{l}\text { Toenails of } \\
\text { participants with } \\
\text { onychomycosis after } \\
\text { application of } \\
\text { formulated nail } \\
\text { lacquer twice daily } \\
\text { for } 24 \text { weeks. }\end{array}$ & $\begin{array}{l}\text { Enhanced drug } \\
\text { permeation across human } \\
\text { nail plates. }\end{array}$ & [54] \\
\hline & Ciclopirox & Urea & $\begin{array}{l}\text { Previously prepared } \\
\text { hoof membrane was } \\
\text { utilized in a Franz } \\
\text { diffusion. }\end{array}$ & $\begin{array}{l}\text { Enhanced drug } \\
\text { permeation across bovine } \\
\text { hoof membrane. }\end{array}$ & [55] \\
\hline & Ciclopirox & $5 \%$ papain & $\begin{array}{l}\text { Human Nail } \\
\text { Clipping }\end{array}$ & $\begin{array}{l}\text { Three-fold enhanced drug } \\
\text { penetration as compared } \\
\text { to marketed ciclopirox } \\
\text { lacquer. }\end{array}$ & [56] \\
\hline \multirow[t]{7}{*}{$\begin{array}{l}\text { Physical } \\
\text { methods }\end{array}$} & Ketoconazole & Etching & $\begin{array}{l}\text { Human nails } \\
\text { received chemical } \\
\text { etching with } \\
\text { Phosphoric Acid gel, } \\
10 \% \text { for 1-minute. }\end{array}$ & $\begin{array}{l}\text { Six-fold enhanced } \\
\text { permeation of drug in nail } \\
\text { plates undergone etching } \\
\text { as compared with nail } \\
\text { plates without etching. }\end{array}$ & [57] \\
\hline & $\begin{array}{l}\text { Aminolevulinic } \\
\text { acid (ALA) }\end{array}$ & $\begin{array}{l}\text { Photodynamic } \\
\text { therapy } \\
\text { (PDT) }\end{array}$ & $\begin{array}{l}\text { Toenails detached } \\
\text { through routine nail } \\
\text { surgery. }\end{array}$ & $\begin{array}{l}\text { Drug penetration was } \\
\text { improved across nail } \\
\text { plate. }\end{array}$ & [58] \\
\hline & Sertaconazole & $\begin{array}{l}\text { Nail patch } \\
\text { triggering } \\
\text { improved } \\
\text { hydration }\end{array}$ & $\begin{array}{l}\text { Sertaconazole } \\
3.63 \mathrm{mg} \text { nail patch } \\
\text { placed on human } \\
\text { nail, for the } \\
\text { treatment duration of } \\
6 \text { weeks with weekly } \\
\text { replacement of } \\
\text { patches. }\end{array}$ & $\begin{array}{l}\text { Penetration was } \\
\text { remarkably enhanced. } \\
\text { Drug concentrations were } \\
\text { found to be above } \\
\text { minimum inhibitory } \\
\text { concentration at } 2,4 \text {, and } \\
6 \text { weeks. }\end{array}$ & [59] \\
\hline & Terbinafine & Microporation & $\begin{array}{l}\text { Nails of patients } \\
\text { with onychomycosis }\end{array}$ & $\begin{array}{l}\text { Though transungual } \\
\text { permeation of terbinafine } \\
\text { was increased }\end{array}$ & [60] \\
\hline & Griseofulvin & Iontophoresis & $\begin{array}{l}\text { Franz diffusion cells } \\
\text { fitted with } \\
\text { customized Teflon } \\
\text { nail holder. }\end{array}$ & $\begin{array}{l}\approx 8 \text {-fold enhanced drug } \\
\text { transport across nail plate } \\
\text { with iontophoresis }\end{array}$ & [47] \\
\hline & {$\left[{ }^{3} \mathrm{H}\right]$ ketoconazole } & Hydration & $\begin{array}{l}\text { Franz-type diffusion } \\
\text { cells, specially } \\
\text { designed to grip the } \\
\text { human nail. }\end{array}$ & $\begin{array}{l}\text { Enhanced penetration of } \\
{\left[{ }^{3} \mathrm{H}\right] \text { ketoconazole across }} \\
\text { nails undergone } \\
\text { hydration. }\end{array}$ & [39] \\
\hline & Mannitol & $\begin{array}{l}\text { Anodal } \\
\text { iontophoresis }\end{array}$ & $\begin{array}{l}\text { Human nails with } \\
\text { neutral and charged } \\
\text { molecules }\end{array}$ & $\begin{array}{l}\text { Enhanced mannitol } \\
\text { transport across nail plate } \\
\text { as compared to passive } \\
\text { diffusion. }\end{array}$ & [5] \\
\hline
\end{tabular}




\begin{tabular}{|c|c|c|c|c|c|}
\hline & Urea & $\begin{array}{l}\text { Anodal } \\
\text { iontophoresis }\end{array}$ & $\begin{array}{l}\text { Human nails with } \\
\text { neutral and charged } \\
\text { molecules. }\end{array}$ & $\begin{array}{l}\text { Enhanced urea transport } \\
\text { across nail plate as } \\
\text { compared to passive } \\
\text { diffusion }\end{array}$ & [5] \\
\hline & $\begin{array}{l}\text { Terbinafine } \\
\text { hydrochloride } \\
\text { and } \\
\text { 5-FU }\end{array}$ & Etching & $\begin{array}{l}\text { Human nails } \\
\text { received chemical } \\
\text { etching with } 10 \% \\
\text { (w/w) phosphoric } \\
\text { acid for a minute. }\end{array}$ & $\begin{array}{l}\text { Drug penetration was } \\
\text { enhanced because of } \\
\text { pretreatment with the PA } \\
\text { gels. }\end{array}$ & [61] \\
\hline & Ciclopirox & Ultrasound & $\begin{array}{l}\text { Canine hoof } \\
\text { membrane was } \\
\text { exposed to three } \\
\text { energy levels for } \\
\text { duration of } 2 \\
\text { minutes with power } \\
\text { of } 1.5 \mathrm{~W} / \mathrm{cm}^{2} \text {. Blue } \\
\text { dye was utilized as a } \\
\text { marker. }\end{array}$ & $\begin{array}{l}1.5 \text {-folds greater } \\
\text { penetration as compared } \\
\text { to passive drug delivery. }\end{array}$ & [62] \\
\hline \multirow[t]{2}{*}{$\begin{array}{l}\text { Mechanical } \\
\text { methods }\end{array}$} & $\begin{array}{l}\text { 5-FU and } \\
\text { flurbiprofen }\end{array}$ & Nail abrasion & $\begin{array}{l}\text { Human Nail } \\
\text { Clipping obtained } \\
\text { from healthy } \\
\text { volunteers and } \\
\text { studied in diffusion } \\
\text { cell. }\end{array}$ & $\begin{array}{l}\text { Filing has shown to } \\
\text { double the permeability } \\
\text { coefficient of 5-FU and } \\
\text { flurbiprofen through the } \\
\text { nail plate in vitro. }\end{array}$ & [16] \\
\hline & $\begin{array}{l}\text { Ketoconazole } \\
(2 \%) \text { or } \\
\text { Oxiconazole } \\
(1 \%)\end{array}$ & $\begin{array}{l}\text { Avulsion } \\
\text { followed by } \\
\text { topical } \\
\text { application of } \\
\text { drugs. }\end{array}$ & $\begin{array}{l}\text { Nails of patients } \\
\text { with onychomycosis. }\end{array}$ & $\begin{array}{l}\text { Enhanced drug delivery } \\
\text { into nails, } 56 \% \text { patients } \\
\text { were cured with this } \\
\text { approach. }\end{array}$ & [63] \\
\hline
\end{tabular}

\subsection{Chemical strategies}

Chemical strategies employ chemical substances into topical preparations for enhancing drug penetration via nails. Numerous studies have been reported that utilized chemical enhancers for compromising the nail barrier in order to increase the ingress of drugs across the nail plate [39, 57, 64-66]. Different mechanisms of drug penetration into nail have been identified. For instance, penetrations enhancers with keratolytic activity, such as salicylic acid, urea, and papain, work by disrupting secondary sulfide linkages and tertiary structure of proteins. [67, 68]. Keratolytic agents can generate new pores that are connected to the transport channels, thereby play a role in increased drug penetration into nails. Nair and co-workers reported a moderate rise in terbinafine penetration passively in 24 hours when the nails remained soaked in solution of salicylic acid (4 mg/ml) [66]. However, a significant increase in terbinafine permeation was recorded when this experimental setup was coupled with iontophoresis, which is a physical permeation enhancement technique. Another approach is using keratolytic enzymes such as keratinase. Keratinase is an enzyme produced by Paecilomyces marquandii, which acts on intracellular matrix and corneocytes thereby reducing 
nail barrier properties. Therefore, keratinase enzyme is another option to promote permeation across nail plate by reducing nail barrier functions [52].

Combination of different chemical enhancers often provides the best outcomes. For instance, a profound rise in penetration was witnessed when combination of $\mathrm{N}$-(2mercaptopropionyl) glycine and urea was employed in comparison with the results when urea was used alone [68]. Solvents like, dimethyl sulfoxide (DMSO) can also be employed for the purpose of altering lipid concentrations and conformation of keratin structure in nail plate. A sharp rise of approximately $50 \%$ in permeation of salicylic acid, itraconazole, and radiolabeled urea was observed in intermediate nail plate when DMSO was used as compared with that from the control samples containing saline as solvent [69].

\subsection{Physical methods}

Applications of physical techniques are widely studied for transdermal and topical delivery of drugs [70]. Physical methods are generally expensive and require additional equipment and technology, however, these are proven to be more effective than chemical techniques for enhancement of topical drug penetration into nails [71]. Many of these physical methods create mechanical influence on the nail tissues by abrasion or generating channels that may permit the penetration of drugs of higher molecular weight and hydrophilic agents [42]. In this section, several physical methods that are currently in use are briefly discussed.

\subsubsection{Etching}

Etching is a process of nail surface modification by chemicals such as phosphoric acid and tartaric acids that results into development of profuse microporosities in nail plate. Formation of microporosities enhances the surface area and wettability, and reduces the contact angle thus offers perfect surface for material bonding. Results of Atomic Force Microscopy (AFM) showed that mean surface roughness was enhanced 1.3 times by phosphoric acid and 1.7 times by tartaric acid, when these chemicals were applied as etchants on nail surface. After the etching of nail plate, hydrophilic and sustained release polymer film as a drug delivery system can be applied effectively. Bioadhesion, i.e. adherence of biological or synthetic substances to biological substrates, must be taken into account. The greater the bioadhesion, the greater the transugnual drug penetration from bioadhesive systems applied on nails [26, 57, 72].

\subsubsection{Iontophoresis}

Iontophoresis is the delivery of substances through a membrane by applying a mild electric field, thus enhancing the movement of ionic compounds into and through the biological membranes [73]. Process of iontophoresis has been practically used for clinical purposes including penetration of antibiotics, treatment of herpes simplex, cutaneous anesthesia and for 
management of hyperhidrosis [74]. Iontophoresis has now found its applications in transdermal drug delivery as well as other fields such as orthopedic and dentistry [75-77]. The enhanced drug delivery is influenced by various factors such as electrophoresis, electro-repulsion, existence of interaction between charge on ionic permeant and electrical field, electroporation, flow of solvents in previously existing and newly formed charged passages (electro-osmosis). Different mechanisms operate for ionic and neutral permeants during iontophoretic treatment. Enhanced movement and improved penetration of neutral permeants depend upon electroosmosis. Electrophoresis and electro-osmosis processes operate simultaneously for ionic permeants. Furthermore, it has been observed that impact of electric current on nails is reversible and nails will regain their normal barrier properties post-iontophoretic treatment [5].

Various studies have been reported where enhanced drug permeation was achieved using iontophoresis. For instance, Murthy and co-workers have demonstrated enhanced permeation of salicylic acid across the nail plate by applying an electrical field [42]. Many other studies have revealed an enhanced terbinafine permeation with iontophoresis and are extensively reviewed by Darkes and co-workers [78]. Terbinafine is an ionic drug, which is completely ionized at $\mathrm{pH} 3.0$, thus can be iontophoretically deliverable at this $\mathrm{pH}$ with great possibility of electromigration of the molecules [79]. A combination of iontophoresis and nail abrasion is another option that can synergistically enhance the permeation of terbinafine [80].

\subsubsection{Microporation of the nail plate}

Microporation involves drilling of tiny holes in nail plate without damaging the nail bed. PathFormer (Path Scientific, Carlisle, USA) is a Food and Drug Administration of United States (US-FDA) approved device, which is used for microporation. Once micropores are formed, topical drugs are applied superficially and micropores allow them to reach the nail bed [71, 81-83]. Recently, dermaroller (Infinitive Beauty, Birmingham, UK) was used by Chiu and co-workers for producing micropores on surface of nail [84]. This group of researchers witnessed sustained delivery into the deeper layers of nail after application of polymeric nanoparticles loaded with a lipophilic fluorophore on porated nails surfaces in comparison with non-porated nails [49]. More recently, Cordoba Diaz and co-workers demonstrated a 3-4-fold increase in ciclopirox permeation followed by mechanical fenestration after 42 days application [85], thus suggested it as a pretreatment strategy to address onychomycosis.

\subsubsection{Laser ablation}

Laser induced transungual permeation enhancement is a minimally invasive technique that is considered superior than the other physical enhancement techniques [86]. Laser disrupts the nail barrier, thereby producing microchannels that facilitate permeation of molecules at a rapid 
rate [87]. Nail barrier disruption is commonly achieved by PLEASE ${ }^{\circledR}$ (Precise Laser Epidermal System) utilizing Er:YAG fractional ablative laser. This system operates by emitting infrared light at a wavelength of $2940 \mathrm{~nm}$, which quickly couples with water molecules in the nail plate. As a result, water evaporates and leaves behind microchannels that are exploited by the drug molecules to escape deep into the nail plate and reach the nail bed [87]. Recently, nail barrier disruption was achieved by a new combination of chemical enhancers such as urea or thioglycolic acid coupled with fractional $\mathrm{CO}_{2}$ laser. Results demonstrated a $100 \%$ accumulation of amorolfine hydrochloride when thioglycolic acid was used as a permeation enhancer along with $\mathrm{CO}_{2}$ laser. While urea coupled with $\mathrm{CO}_{2}$ laser could produce a $57 \%$ accumulation of drug [86]. Furthermore, these results suggested a potential new chemical and physical synergy.

Long-term laser exposure can significantly and permanently damage the stratum corneum and nail plate because of heat production, thus presents a potential challenge to laser facilitated topical and transdermal drug delivery [88]. Ultrashort laser bursts at nanosecond and femtosecond scale can significantly ablate hard tissues such as nails without causing any thermal damage to them [89-91]. Using the femtosecond laser exposure concept, Vanstone and co-workers demonstrated a precise femtosecond laser ablation of nail plate which resulted in formation of an array of 100 pores per $0.2 \mathrm{~cm}^{2}$ area of nail, which resulted in a significantly higher drug permeation ( $10^{3}$-fold). Thus, precise femtosecond laser ablation could possibly be used for sustained topical delivery of antifungals for the treatment of onychomycosis [92].

\subsubsection{Low frequency ultrasound}

Low frequency ultrasound waves have been introduced as a novel technique for enhancing drug permeation through the nail plate for treating fungal nail infections [44, 93]. The exact mechanism by which ultrasound facilitates enhanced permeation is somewhat elusive, however, it is believed that ultrasound creates cavitations in nail's structure hereby promoting transungual permeation [29]. Abadi and Zderic have developed a computer-assisted ultrasound device for the treatment of onychomycosis. They used canine nails as a surrogate to study the effect of ultrasound on permeation. They exposed water soaked canine nails to ultrasound device operating at a frequency of $1.5 \mathrm{~W} / \mathrm{cm}^{2}$ for 30,60 , and $120 \mathrm{~s}$. Result demonstrated that exposure of low frequency ultrasound for $120 \mathrm{~s}$ proved to be optimal with permeability factor of 1.5 as compared with $30 \mathrm{~s}$ and $60 \mathrm{~s}$ where permeability factor was 1.3 , and the reported method could be used for the treatment of onychomycosis [94].

\subsection{Mechanical methods}

\subsubsection{Abrasion of the nail plate}


Abrasion of nail surface is one of the commonly used approach to reduce its thickness or completely destroy it. This approach is traditionally more frequently used by podiatrist then the dermatologists [95]. Reducing nail thickness by abrasion could potentially enhance penetration of topically applied drugs [96]. Abrasion is done by sanding, filing or debridement, that cause removal of dorsal layer and lessen the thickness of nail plate [48, 71, 81, 97-99]. Practically it is carried out with sandpaper that can be linked to a dermabrader device. It is practical and can be performed with sandpaper, which can be connected to a dermabrader [97] and dental drills $[48,71]$. Although this technique shows lesser success rates as compared with physical techniques, but combining oral treatment with abrasion of nail plate results into higher effectiveness and reduced recurrence of infection [100]. A study was conducted involving diabetic patients with white superficial onychomycosis (WSO) and distal-lateral subungual onychomycosis (DLSO) for evaluation of effect of combined topical treatment along with abrasion of nail plate. An electric grinder with an aspirator was used for slight drilling of nail surface and for reducing its thickness to $1-2 \mathrm{~mm}$. Results of this study revealed that lower $(16.7 \%)$ cure rate for onychomycosis in comparison with oral treatment, while few participants with WSO were cured and few participants with DLSO exhibited improvement [82].

\subsubsection{Nail avulsion}

Total or partial nail avulsion includes the surgical nail removal of whole nail plate or removal of affected area of nail plate with the help of local anesthesia. Softening of nail plate is previously done with the help of keratolytic agents such as salicylic acid and urea, for the purpose of avulsion. In clinical studies, urea alone or in combination with salicylic acid has been utilized for nonsurgical avulsion before applying topical therapy of onychomycosis [101].

\section{Conclusions}

Nail infection is reported to affect about 5.5 percent of the population worldwide [102] and is a challenging condition to address. It can also affect the adjacent soft tissue, and causes thickened, discolored and disfigured nail negatively affecting both the personal and social life style [20]. Onychomycosis is also known to affect toe nail preferentially due to low blood supply and conducive environment for the fungal growth [103]. Treatment is not always warranted and mainly depends on the causative organism and nail's status. The options include but not limited to the topical and oral antifungal medications, and even surgical removal of the affected nail plate, although topical treatment takes much longer time due to nail barrier. Oral antifungal therapy has shown success; however, disease relapse rates are higher. Of the note, topical drug delivery via the nail is very complicated and thus many innovative techniques have been employed, many of the prominent ones have discussed in this manuscript. A number of 
individual and combination therapies are available to address this and more recent therapeutic approaches are focused on topical treatments to avoid systemic side effects. Given the worldwide prevalence and social impact of the disease, more effective, quick and nail sparing therapies are likely to emerge in near future.

\section{Conflict of Interest}

None declared

\section{Acknowledgments}

We acknowledge COMSATS University Islamabad, Lahore campus for providing facilities. This study received no funding from any source.

\section{References}

[1] Grover C, Khurana A. An update on treatment of onychomycosis. Mycoses. 2012;55(6):541-

51.

[2] Daniel RC. Onychomycosis: Burden of disease and the role of topical antifungal treatment. Journal of Drugs in Dermatology. 2013;12(11):1263-6.

[3] Elewski BE. Onychomycosis: Pathogenesis, diagnosis, and management. Clinical Microbiology Reviews. 1998;11(3):415-29.

[4] Moriarty B, Hay R, Morris-Jones R. The diagnosis and management of tinea. BMJ (Online). 2012;344(7865).

[5] Hao J, Li SK. Transungual iontophoretic transport of polar neutral and positively charged model permeants: effects of electrophoresis and electroosmosis. Journal of pharmaceutical sciences. 2008;97(2):893-905.

[6] Shivakumar HN, Juluri A, Desai BG, Murthy SN. Ungual and Transungual drug delivery. Drug Development and Industrial Pharmacy. 2012;38(8):901-11.

[7] Hay R. Literature review. Journal of the European Academy of Dermatology and Venereology. 2005;19:1-7.

[8] Thomas J, Jacobson GA, Narkowicz CK, Peterson GM, Burnet H, Sharpe C. Toenail onychomycosis: an important global disease burden. Journal of Clinical Pharmacy and Therapeutics. 2010;35(5):497-519.

[9] Brown M, Turner R, Wevrett SR. Use of in vitro performance models in the assessment of drug delivery across the human nail for nail disorders. Expert opinion on drug delivery. 2018;15(10):983-9.

[10] De Berker D. Nail anatomy. Clinics in Dermatology. 2013;31(5):509-15.

[11] Garson JC, Baltenneck F, Leroy F, Riekel C, Müller M. Histological structure of human nail as studied by synchrotron X-ray microdiffraction. Cellular and Molecular Biology. 2000;46(6):1025-34.

[12] Dawber RPR. The ultrastructure and growth of human nails. Archives of Dermatological Research. 1980;269(2):197-204.

[13] Jemec GBE, Agner T, Serup J. Transonychial water loss: Relation to sex, age and nail-plate thickness. British Journal of Dermatology. 1989;121(4):443-6.

[14] Cohen JL, Scher RK, Pappert AS. The nail and fungus infections. In: Elewski BE, editor. Cutaneous fungal infections. New York: Igaku-Shoin Inc.; 1992. p. 106-22.

[15] Murdan S. Drug delivery to the nail following topical application. International Journal of Pharmaceutics. 2002;236(1-2):1-26. 
[16] Kobayashi Y, Miyamoto M, Sugibayashi K, MORIMOTO Y. Drug permeation through the three layers of the human nail plate. Journal of pharmacy and pharmacology. 1999;51(3):271-8.

[17] Jemec G, Agner T, Serup J. Transonychial water loss: relation to sex, age and nail-plate thickness. British Journal of Dermatology. 1989;121(4):443-6.

[18] Walters KA, Flynn GL, Marvel JR. Physicochemical characterization of the human nail: solvent effects on the permeation of homologous alcohols. Journal of pharmacy and pharmacology. 1985;37(11):771-5.

[19] De Berker D, Wojnarowska F, Sviland L, Westgate GE, Dawber RP, Leigh IM. Keratin expression in the normal nail unit: markers of regional differentiation. The British journal of dermatology. 2000;142(1):89-96.

[20] Lipner SR, Scher RK. Onychomycosis: Treatment and prevention of recurrence. Journal of the American Academy of Dermatology. 2019;80(4):853-67.

[21] Jiaravuthisan MM, Sasseville D, Vender RB, Murphy F, Muhn CY. Psoriasis of the nail: Anatomy, pathology, clinical presentation, and a review of the literature on therapy. Journal of the American Academy of Dermatology. 2007;57(1):1-27.

[22] Hay RJ, Baran R. Onychomycosis: A proposed revision of the clinical classification. Journal of the American Academy of Dermatology. 2011;65(6):1219-27.

[23] Hay RJ, Baran R, Moore MK, Wilkinson JD. Candida onychomycosis - an evaluation of the role of Candida species in nail disease. British Journal of Dermatology. 1988;118(1):47-58.

[24] Gupta AK, Simpson FC. New therapeutic options for onychomycosis. Expert Opinion on Pharmacotherapy. 2012;13(8):1131-42.

[25] Gupta AK, Paquet M, Simpson FC. Therapies for the treatment of onychomycosis. Clinics in Dermatology. 2013;31(5):544-54.

[26] Repka MA, O'Haver J, See CH, Gutta K, Munjal M. Nail morphology studies as assessments for onychomycosis treatment modalities. International Journal of Pharmaceutics. 2002;245(1-2):2536.

[27] Scher RK. Onychomycosis: Therapeutic update. Journal of the American Academy of Dermatology. 1999;40(6 II):S21-S6.

[28] Tanriverdi ST, Özer O. Novel topical formulations of Terbinafine- $\mathrm{HCl}$ for treatment of onychomycosis. European Journal of Pharmaceutical Sciences. 2013;48(4-5):628-36.

[29] Walters KA, Abdalghafor HM, Lane ME. The human nail-barrier characterisation and permeation enhancement. International journal of pharmaceutics. 2012;435(1):10-21.

[30] Brown M, Khengar RH, Turner RB, Forbes B, Traynor M, Evans C, et al. Overcoming the nail barrier: a systematic investigation of ungual chemical penetration enhancement. International journal of pharmaceutics. 2009;370(1-2):61-7.

[31] Smith KA, Hao J, Li SK. Effects of ionic strength on passive and iontophoretic transport of cationic permeant across human nail. Pharmaceutical research. 2009;26(6):1446-55.

[32] Murdan S. Enhancing the nail permeability of topically applied drugs. Expert opinion on drug delivery. 2008;5(11):1267-82.

[33] de Berker D, editor Management of psoriatic nail disease. Seminars in cutaneous medicine and surgery; 2009: No longer published by Elsevier.

[34] Kobayashi Y, Komatsu T, Sumi M, Numajiri S, Miyamoto M, Kobayashi D, et al. In vitro permeation of several drugs through the human nail plate: relationship between physicochemical properties and nail permeability of drugs. European journal of pharmaceutical sciences. 2004;21(4):471-7.

[35] Roberts D, Evans E. Subungual dermatophytoma complicating dermatophyte onychomycosis. The British journal of dermatology. 1998;138(1):189.

[36] Vikas A, Rashmin P, Mrunali P, Chavan RB, Kaushik T. Mechanistic Insights of Formulation Approaches for the Treatment of Nail Infection: Conventional and Novel Drug Delivery Approaches. AAPS PharmSciTech. 2020;21(2):67. 
[37] WALTERS KA, FLYNN GL, MARVEL JR. Physicochemical characterization of the human nail: permeation pattern for water and the homologous alcohols and differences with respect to the stratum corneum*. Journal of Pharmacy and Pharmacology. 1983;35(1):28-33.

[38] Smith KA, Hao J, Li SK. Effects of organic solvents on the barrier properties of human nail. Journal of pharmaceutical sciences. 2011;100(10):4244-57.

[39] Gunt HB, Kasting GB. Effect of hydration on the permeation of ketoconazole through human nail plate in vitro. European Journal of pharmaceutical sciences. 2007;32(4-5):254-60.

[40] Hui X, Wester RC, Barbadillo S, Lee C, Patel B, Wortzmman M, et al. Ciclopirox delivery into the human nail plate. Journal of pharmaceutical sciences. 2004;93(10):2545-8.

[41] Cutrín-Gómez E, Anguiano-Igea S, Delgado-Charro MB, Gómez-Amoza JL, Otero-Espinar FJ. Effect on Nail Structure and Transungual Permeability of the Ethanol and Poloxamer Ratio from Cyclodextrin-Soluble Polypseudorotaxanes Based Nail Lacquer. Pharmaceutics. 2018;10(3):156.

[42] Narasimha Murthy S, Wiskirchen DE, Paul Bowers C. Iontophoretic drug delivery across human nail. Journal of pharmaceutical sciences. 2007;96(2):305-11.

[43] Elsayed MM. Development of topical therapeutics for management of onychomycosis and other nail disorders: a pharmaceutical perspective. Journal of Controlled Release. 2015;199:132-44.

[44] Shanbhag PP, Jani U. Drug delivery through nails: Present and future. New Horizons in Translational Medicine. 2017;3(5):252-63.

[45] Mertin D, LIPPOLD BC. In-vitro permeability of the human nail and of a keratin membrane from bovine hooves: prediction of the penetration rate of antimycotics through the nail plate and their efficacy. Journal of pharmacy and pharmacology. 1997;49(9):866-72.

[46] Smith KA, Hao J, Li SK. Influence of pH on transungual passive and iontophoretic transport. Journal of pharmaceutical sciences. 2010;99(4):1955-67.

[47] Murthy SN, Waddell DC, Shivakumar H, Balaji A, Bowers CP. Iontophoretic permselective property of human nail. Journal of dermatological science. 2007;46(2):150-2.

[48] Shivakumar H, Juluri A, Desai B, Murthy SN. Ungual and transungual drug delivery. Drug development and industrial pharmacy. 2012;38(8):901-11.

[49] Saner MV, Kulkarni AD, Pardeshi CV. Insights into drug delivery across the nail plate barrier. Journal of drug targeting. 2014;22(9):769-89.

[50] Van Hoogdalem E, Van den Hoven W, Terpstra I, Van Zijtveld J, Verschoor J, Visser J. Nail penetration of the antifungal agent oxiconazole after repeated topical application in healthy volunteers, and the effect of acetylcysteine. European journal of pharmaceutical sciences. 1997;5(3):119-27.

[51] Hui X, Chan TC, Barbadillo S, Lee C, Maibach HI, Wester RC. Enhanced econazole penetration into human nail by 2-n-nonyl-1, 3-dioxolane. Journal of pharmaceutical sciences. 2003;92(1):142-8.

[52] Mohorčič M, Torkar A, Friedrich J, Kristl J, Murdan S. An investigation into keratinolytic enzymes to enhance ungual drug delivery. International journal of pharmaceutics. 2007;332(12):196-201.

[53] Nair AB, Sammeta SM, Vaka SRK, Murthy SN. A study on the effect of inorganic salts in transungual drug delivery of terbinafine. Journal of Pharmacy and Pharmacology. 2009;61(4):431-7.

[54] Angelo T, Borgheti-Cardoso LN, Gelfuso GM, Taveira SF, Gratieri T. Chemical and physical strategies in onychomycosis topical treatment: A review. Medical mycology. 2016;55(5):461-75.

[55] Thapa RK, Choi JY, Go TG, Kang MH, Han SD, Jun J-H, et al. Development of ciclopirox nail lacquer with enhanced permeation and retention. Archives of pharmacal research. 2016;39(7):9539.

[56] Khattab A, Shalaby S. Optimized Ciclopirox-Based Eudragit RLPO Nail Lacquer: Effect of Endopeptidase Enzyme as Permeation Enhancer on Transungual Drug Delivery and Efficiency Against Onychomycosis. AAPS PharmSciTech. 2018;19(3):1048-60.

[57] Repka MA, Mididoddi PK, Stodghill SP. Influence of human nail etching for the assessment of topical onychomycosis therapies. International journal of pharmaceutics. 2004;282(1-2):95-106. 
[58] Donnelly RF, McCarron PA, Lightowler JM, Woolfson AD. Bioadhesive patch-based delivery of 5-aminolevulinic acid to the nail for photodynamic therapy of onychomycosis. Journal of controlled release. 2005;103(2):381-92.

[59] Susilo R, Korting HC, Greb W, Strauss UP. Nail penetration of sertaconazole with a sertaconazole-containing nail patch formulation. American journal of clinical dermatology. 2006;7(4):259-62.

[60] Boker A, Bea Y, Gowrishankar T, editors. A double-blind, placebo-controlled, pilot study of $1 \%$ terbinafine cream delivered via toenail microconduits for the treatment of subungual onychomycosis. Poster presented at the 65th annual meeting of the American Academy of Dermatology, Washington, DC; 2007.

[61] Vaka SRK, Murthy SN, O'Haver JH, Repka MA. A platform for predicting and enhancing model drug delivery across the human nail plate. Drug development and industrial pharmacy.

2011;37(1):72-9.

[62] Kushwaha A, Murthy RN, Murthy SN, Elkeeb R, Hui X, Maibach HI. Emerging therapies for the treatment of ungual onychomycosis. Drug development and industrial pharmacy. 2015;41(10):157581.

[63] Grover C, Bansal S, Nanda S, Reddy BS, Kumar V. Combination of surgical avulsion and topical therapy for single nail onychomycosis: a randomized controlled trial. The British journal of dermatology. 2007;157(2):364-8.

[64] Hao J, Smith KA, Li SK. Chemical method to enhance transungual transport and iontophoresis efficiency. International journal of pharmaceutics. 2008;357(1-2):61-9.

[65] Nair AB, Kim HD, Chakraborty B, Singh J, Zaman M, Gupta A, et al. Ungual and trans-ungual iontophoretic delivery of terbinafine for the treatment of onychomycosis. Journal of pharmaceutical sciences. 2009;98(11):4130-40.

[66] Nair AB, Sammeta SM, Kim HD, Chakraborty B, Friden PM, Murthy SN. Alteration of the diffusional barrier property of the nail leads to greater terbinafine drug loading and permeation. International journal of pharmaceutics. 2009;375(1-2):22-7.

[67] Kobayashi Y, Miyamoto M, Sugibayashi K, MORIMOTO Y. Enhancing effect of $\mathrm{N}$-acetyl-Icysteine or 2-mercaptoethanol on the in vitro permeation of 5-fluorouracil or tolnaftate through the human nail plate. Chemical and pharmaceutical bulletin. 1998;46(11):1797-802.

[68] Malhotra GG, Zatz JL. Investigation of nail permeation enhancement by chemical modification using water as a probe. Journal of pharmaceutical sciences. 2002;91(2):312-23.

[69] Vejnovic I, Simmler L, Betz G. Investigation of different formulations for drug delivery through the nail plate. International journal of pharmaceutics. 2010;386(1-2):185-94.

[70] Neves Borgheti-Cardoso L, M Gelfuso G, FV Lopez R, Gratieri T. Topical and transdermal delivery of drug-loaded nano/microsystems with application of physical enhancement techniques. Current drug targets. 2016;17(13):1545-59.

[71] Barot BS, Parejiya PB, Patel HK, Mehta DM, Shelat PK. Drug delivery to the nail: therapeutic options and challenges for onychomycosis. Critical Reviews ${ }^{\mathrm{TM}}$ in Therapeutic Drug Carrier Systems. 2014;31(6).

[72] Mididoddi P, Prodduturi S, Repka M. Influence of tartaric acid on the bioadhesion and mechanical properties of hot-melt extruded hydroxypropyl cellulose films for the human nail. Drug development and industrial pharmacy. 2006;32(9):1059-66.

[73] Borgheti-Cardoso LN, Angelo T, Gelfuso GM, Lopez RF, Gratieri T. Topical and Transdermal Delivery of Drug-Loaded Nano/ Microsystems with Application of Physical Enhancement Techniques. Current drug targets. 2016;17(13):1545-59.

[74] Kassan DG, Lynch AM, Stiller MJ. Physical enhancement of dermatologic drug delivery: iontophoresis and phonophoresis. Journal of the American Academy of Dermatology. 1996;34(4):657-66.

[75] Horwath-Winter J, Schmut O, Haller-Schober E, Gruber A, Rieger G. lodide iontophoresis as a treatment for dry eye syndrome. British journal of ophthalmology. 2005;89(1):40-4. 
[76] Nowicki K, Heidt JR, Colosimo A. Effects of iontophoretic versus injection administration of dexamethasone. Medicine and science in sports and exercise. 2002;34(8):1294-301.

[77] Chen L-J, Meng Q-F, Chen Y-M, Smales R, Yip K-K. Effect of fluoride iontophoresis on the microtensile bond strength between dentin and two adhesive systems. Journal of dentistry.

2008;36(9):697-702.

[78] Darkes MJ, Scott L, Goa KL. Terbinafine: a review of its use in onychomycosis in adults. Am J Clin Dermatol. 2003;4(1):39-65.

[79] Nair AB, Vaka SR, Sammeta SM, Kim HD, Friden PM, Chakraborty B, et al. Trans-ungual iontophoretic delivery of terbinafine. J Pharm Sci. 2009;98(5):1788-96.

[80] Nair AB, Sammeta SM, Kim HD, Chakraborty B, Friden PM, Murthy SN. Alteration of the diffusional barrier property of the nail leads to greater terbinafine drug loading and permeation. Int J Pharm. 2009;375(1-2):22-7.

[81] Gupta AK, Paquet M. Improved efficacy in onychomycosis therapy. Clinics in dermatology. 2013;31(5):555-63.

[82] Sumikawa M, Egawa T, Honda I, Yamamoto Y, Sumikawa Y, Kubota M. Effects of foot care intervention including nail drilling combined with topical antifungal application in diabetic patients with onychomycosis. The Journal of dermatology. 2007;34(7):456-64.

[83] Salter SA, Ciocon DH, Gowrishankar TR, Kimball AB. Controlled nail trephination for subungual hematoma. The American journal of emergency medicine. 2006;24(7):875-7.

[84] Chiu WS, Belsey NA, Garrett NL, Moger J, Price GJ, Delgado-Charro MB, et al. Drug delivery into microneedle-porated nails from nanoparticle reservoirs. Journal of Controlled Release.

2015;220:98-106.

[85] Cordoba Diaz D, Losa Iglesias ME, Becerro de Bengoa Vallejo R, Cordoba Diaz M. Transungual Delivery of Ciclopirox Is Increased 3(-)4-Fold by Mechanical Fenestration of Human Nail Plate in an In Vitro Model. Pharmaceutics. 2019;11(1).

[86] Šveikauskaitè I, Pockevičius A, Briedis V. Potential of Chemical and Physical Enhancers for Transungual Delivery of Amorolfine Hydrochloride. Materials. 2019;12(7):1028.

[87] Nguyen HX, Banga AK. Effect of ablative laser on in vitro transungual delivery. Int J Pharm. 2018;544(2):402-14.

[88] Shahzad Y, Louw R, Gerber M, Du Plessis J. Breaching the skin barrier through temperature modulations. Journal of Controlled Release. 2015;202:1-13.

[89] Vogel A, Noack J, Hüttman G, Paltauf G. Mechanisms of femtosecond laser nanosurgery of cells and tissues. Applied Physics B. 2005;81(8):1015-47.

[90] Neev J, Silva LBD, Feit MD, Perry MD, Rubenchik AM, Stuart BC. Ultrashort pulse lasers for hard tissue ablation. IEEE Journal of Selected Topics in Quantum Electronics. 1996;2(4):790-800.

[91] Vanstone S, Stone JM, Gordeev SN, Guy RH. Mechanism of human nail poration by highrepetition-rate, femtosecond laser ablation. Drug delivery and translational research. 2019;9(5):95667.

[92] Vanstone S, Cordery SF, Stone JM, Gordeev SN, Guy RH. Precise laser poration to control drug delivery into and through human nail. Journal of controlled release : official journal of the Controlled Release Society. 2017; 268:72-7.

[93] Abadi D, Zderic V. Ultrasound-mediated nail drug delivery system. Journal of Ultrasound in Medicine. 2011;30(12):1723-30.

[94] Abadi D, Zderic V. Ultrasound-Mediated Nail Drug Delivery System. Journal of Ultrasound in Medicine. 2011;30(12):1723-30.

[95] Di Chiacchio N, Kadunc BV, De Almeida ART, Madeira CL. Nail abrasion. Journal of Cosmetic Dermatology. 2003;2(3-4):150-2.

[96] Maeda N, Mizuno N, Ichikawa K. Nail abrasion: a new treatment for ingrown toe-nails. The Journal of dermatology. 1990;17(12):746-9.

[97] Di Chiacchio N, Kadunc B, De Almeida A, Madeira C. Nail abrasion. Journal of cosmetic dermatology. 2003;2(3-4):150-2. 
[98] Elkeeb R, AliKhan A, Elkeeb L, Hui X, Maibach HI. Transungual drug delivery: current status. International journal of pharmaceutics. 2010;384(1-2):1-8.

[99] Effendy I, Kolczak H, Friederich $\mathrm{H}$. Noncompliance relevant variables in patients with onychomycosis. Wiener medizinische Wochenschrift (1946). 1989;139(15-16):356-9.

[100] Succi IB, Bernardes-Engemann AR, Orofino-Costa R. Intermittent therapy with terbinafine and nail abrasion for dermatophyte toe onychomycosis: a pilot study. Mycoses. 2013;56(3):327-32. [101] Hettinger D, Valinsky M. Treatment of onychomycosis with nail avulsion and topical ketoconazole. Journal of the American Podiatric Medical Association. 1991;81(1):28-32.

[102] Kawa N, Lee KC, Anderson RR, Garibyan L. ONYCHOMYCOSIS: A Review of New and Emerging Topical and Device-based Treatments. The Journal of Clinical and Aesthetic Dermatology. 2019;12(10):29.

[103] Thomas J, Jacobson G, Narkowicz C, Peterson G, Burnet H, Sharpe C. Toenail onychomycosis: an important global disease burden. Journal of clinical pharmacy and therapeutics. 2010;35(5):497519. 